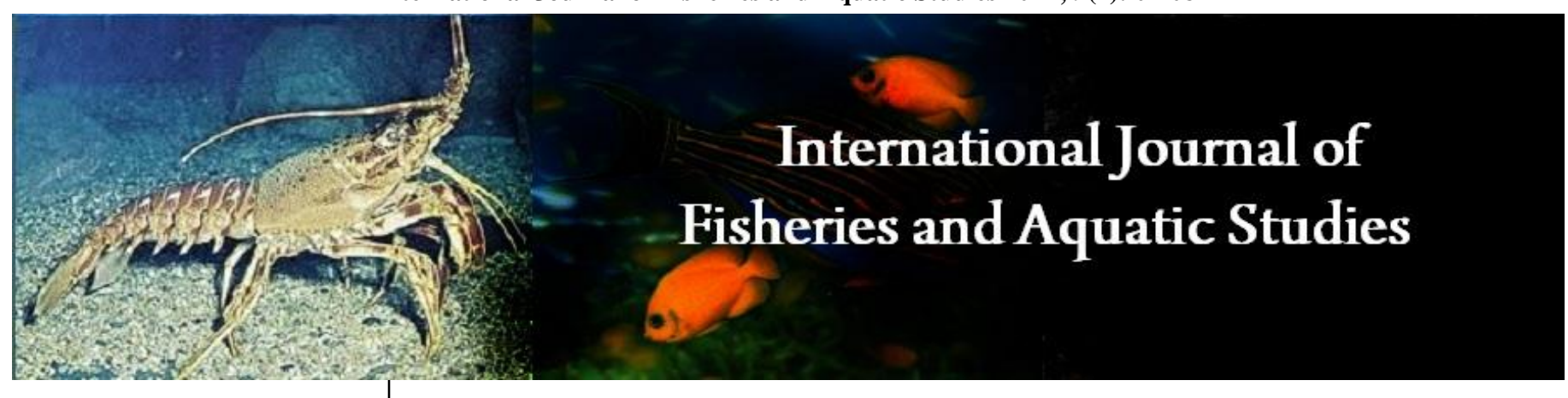

E-ISSN: 2347-5129

P-ISSN: 2394-0506

(ICV-Poland) Impact Value: 5.62

(GIF) Impact Factor: 0.549

IJFAS 2021; 9(2): 01-08

(C) 2021 IJFAS

www.fisheriesjournal.com

Received: 01-01-2021

Accepted: 03-02-2021

\section{Thura Htun}

Demonstrator, Department of

Marine Science, 07011, Sittway

University, Rakhine State,

Myanmar

\section{Khin Myo Myo Tint}

Assistant Lecturer, Department of Marine Science, 12012 ,

Mawlamyine University, Mon

State, Myanmar

\section{Naung Naung 00}

Lecturer, Department of Marine

Science, 07011, Sittway

University, Rakhine State,

Myanmar
Corresponding Author:

Thura Htun

Demonstrator, Department of

Marine Science, 07011, Sittway

University, Rakhine State,

Myanmar

\section{Some intertidal gastropods and bivalves of Thae Chaung Coastal area in Northern Rakhine state of Myanmar}

\author{
Thura Htun, Khin Myo Myo Tint and Naung Naung OO
}

DOI: https://doi.org/10.22271/fish.2021.v9.i2a.2431

\begin{abstract}
Rakhine Coastal Region has a rich diversity of marine life with fisheries. However, there is no publication of basic information of marine bivalves and gastropods such as identification and ecological habitats in Thae Chaung intertidal water, northen Rakhine Coastal Region. The current research on marine mollusks was conducted and emphasize on small geographical area of Thae Chaung intertidal area in December 2019. A total of 11 species belonging to 5 orders, 8 families and 11 genera of gastropods and 6 species belonging to 4 orders, 4 families and 5 genera of bivalves reported from study area were reported. This research paper describes the identification of some economic importance of marine mollusks from Thae Chaung intertidal water in northern Rakhine Coastal Region.
\end{abstract}

Keywords: mollusks, bivalve, gastropod, intertidal, Thae Chaung Coastal area, northen Rakhine, Rakhine Costal region

\section{Introduction}

Myanmar has a long coastline of around $2400 \mathrm{~km}^{2}$ with many marine resources, and is thought to be one of the most undeveloped coastlines in mainland Southeast Asia ${ }^{[1]}$. The coast is divided into three coastal regions; the Rakhine Coastal Region (from the mouth of Naaf River to Mawdin Point, about $740 \mathrm{~km}$ in length), the Ayeyarwady Delta and the Gulf of Martaban Coastal Region (about $460 \mathrm{~km}$ in length) and the Tanintharyi Coastal Region (from the Gulf of Martaban to the mouth of the Pakchan River, about $1200 \mathrm{~km}$ in length) ${ }^{[2]}$.

Northern Rakhine coastal area is the portion of Rakhine Coastal Region of Western Myanmar, and is popular for both local and foreign tourists for its beautiful islands, beaches, and submarine fauna and flora. This includes Nantha Island and near Mayyu estuary designated as Ramsar wetland site in Myanmar, Sittway Point and Hnget Gaung Taung (Myengu Kyun = Western Bo Ron Ga Island), a large island in northern Rakhine State. Land development can be found in many areas around the island.

As Rakhine state is closely related to the coast, the costal and marine ecosystem of this state provides food sources, 20 percents of regional people are working in fishery industry, 90 percents of fishery products are mainly transported to mainland and China and the left 10 percents are consumed by local people.

Furthermore, shellfishes; bivalves and gastropods, which play a vital role, are economic importance. Some are utilized to make handicraft and the other are heavily harvested as food for regional populace. The mollusks are among the most diverse marine invertebrates on the coastal tropical environments and the vast majority is found in intertidal, estuarine and coastal lagoons, and in the shallow areas of continental shelf ${ }^{[3,4]}$.

The phylum mollusca is one of the most distinct animal groups which comprising 100,000 to 200,000 species with above 52,000 species have been identified and characterized ${ }^{[5,6]}$. In Myanmar, there were about 160 species of gastropods and 120 species of bivalves had been reported ${ }^{[7,8]}$. Mollusca is further divided into Scaphopoda, Gastropoda, Cephalopoda, Bivalvia, Polyplacophora, Caudofoveata, Solenogastres, and Monoplacophora ${ }^{[9]}$. People are capturing the molluscs because of their taste and attractiveness characteristics. Molluscs have been utilized for several years for the various purposes. 
Shellfishes are used to create the jewelry decoration. Some molluscs are very harmful to humans. For example, some cone shells can inject the people who get a deadly toxic effect ${ }^{[10]}$. Many molluscs species are apply in traditional medication in various countries of the world ${ }^{[11]}$. Molluscs are play an important role in marine ecosystem, they perform as refining water quality through filtration, balancing algal bloom and improving habitat and substratum complexity through ecosystem engineering ${ }^{[12]}$.

The research area of Thae Chaung is located in the most south-western part of the Sittway. This place is not connected with Sittway Point is not far away from mouth of Kaladan River. Many people from this village relay on livelihood fisheries. Thae Chaug intertidal water owns different habitats; sandy beach, mudflat, estuarine creek and rocky shore. It provides not only shelter and nurseries for marine species but also rich food sources for villagers. This paper aims to evaluate the preliminary checklist of marine shellfishes; bivalves and gastropods of Thae Chaung intertidal coastal water.

\section{Materials and Methods}

This study was conducted in Thae Chaung intertidal water of different habitats such as sandy beach, rocky shore, and mudflat of northen Rakhine Coastal Region in December 2019 (Fig 1). During the survey, samplings of mollscus (gastropods and bivalves) were taken with random hand picking. Both dead and alive specimens were collected in the field. Samples were carefully brought to department laboratory (Marine Science Department, Sittway University) and all collecting samples were soaked in the solution of caustic soda and then was cleaned and dried. In which some alive specimens, fresh meat tissue and some epifaunas were removal with forceps. We brushed the shells to use for further taxonomic works. All shells were preserved in $70 \%$ alcohol for two days, after those specimens were washed for a few hours and dry again in the sun for one day. We took the digital images for each species by using olive oil and pure cotton for a little bit shell lighting. Some of which collecting samples are stored in the laboratory and other are displayed at the Museum of Marine Science Department, Sittway University (MMSD, SU). The classification of bivalves and gastropods was based on shell morphological characteristics such as shape; color and texture according to the literatures of Soe Thu ${ }^{[7]}$, Dance ${ }^{[13]}$, Feinberg ${ }^{[14]}$, Maung win et al ${ }^{[15]}$, Taat Tun Thu ${ }^{[16]}$, Aye Thant Zin et al ${ }^{[17]}$, Thaw Zin Naing Tun et.al ${ }^{[18]}$, Naung Naung Oo ${ }^{[19]}$ and Hossain et al ${ }^{[20]}$.

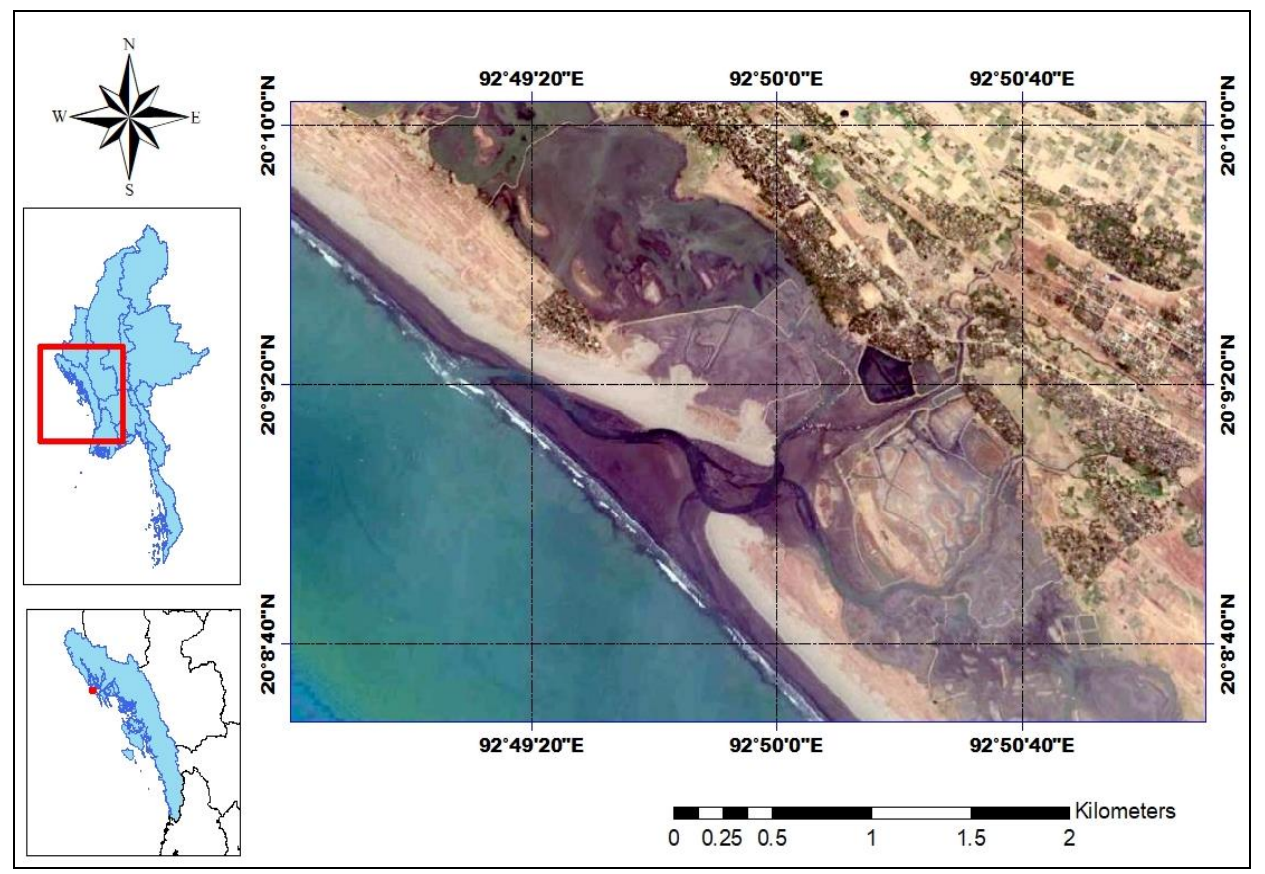

Fig 1: Map showing the collection site of gastropods and bivalves in Thae Chaung intertidal water

\section{Results and Discussion}

The preliminary checklist of marine bivalves and gastropods survey was conducted in Thae Chaung intertidal water in December 2019. This survey was carried out for the intertidal mollusks species in different types of substratum; sandy beach, muddy sand and rocky fringe (Table 1). A total of 17 species of mollusks were recorded on which 11 species of gastropods and 6 species of bivalves were shown in table (1) and figure (2).

Table 1: Record of some intertidal gastropods and bivalves in study area

\begin{tabular}{|c|c|c|c|}
\hline Sr. No. & Species & Common Name & Local Name \\
\hline \multicolumn{4}{|c|}{ Gastropods } \\
\hline 1 & Nerita lineata Gmelin, 1791 & Linear nerite & Jake/ Kha-yu-ma \\
\hline 2 & Turritella duplicata (Linnaeus, 1758) & Duplicate turret shell & Kha-yu-sae-di \\
\hline 3 & Natica tigrina (Röding, 1798) & Spot necklace shell & Kha-yu-lone \\
\hline 4 & Polinices didyma (Röding, 1798) & Common moon snail & Phoe-la-minn \\
\hline 5 & Bursa elegans (G. B. Sowerby I, 1835) & Elegant frog shell & Sue-kha-yu \\
\hline 6 & Thais mutabilis (Link, 1807) & Common rock shell & Kyauk-lone \\
\hline 7 & Murex pecten Lightfoot, 1786 & Venus comb murex & Kha-yu-nga-zin-yine \\
\hline \multicolumn{4}{|c}{$\sim$} \\
\hline
\end{tabular}




\begin{tabular}{|c|c|c|c|}
\hline 8 & Babylonia formosae (G. B. Sowerby II, 1866) & Mud whelk & Nan-dar-hlaing \\
\hline 9 & Nassarius olivaceus (Bruguière, 1789) & Dog whelk & Kha-yu \\
\hline 10 & Pugilina ternatana (Gmelin, 1791) & Ternate melongena & Kha-yu \\
\hline 11 & Turris unedo Kiener, 1839 & Common turrid & Kha-yu-pyat-thet \\
\hline \multicolumn{4}{|c|}{ Bivalves } \\
\hline 12 & Anadara granosa (Linnaeus, 1758) & Granular ark & Thwe-gone/ Gin \\
\hline 13 & Saccostrea cuccullata (Born, 1778) & Hooded oyster & Sar-ka-mar \\
\hline 14 & Crassostrea gigas (Thünberg, 1793) & Giant cupped oyster & Ka-mar \\
\hline 15 & Donax scortum (Linnaeus, 1758) & Leather donax & Thae-kha-yu \\
\hline 16 & Mactra mera Reeve, 1854 & Plain trough shell & Pae-late-pyar \\
\hline 17 & M. violacea Gmelin, 1791 & Violet trough shell & Pae-late-pyar \\
\hline
\end{tabular}

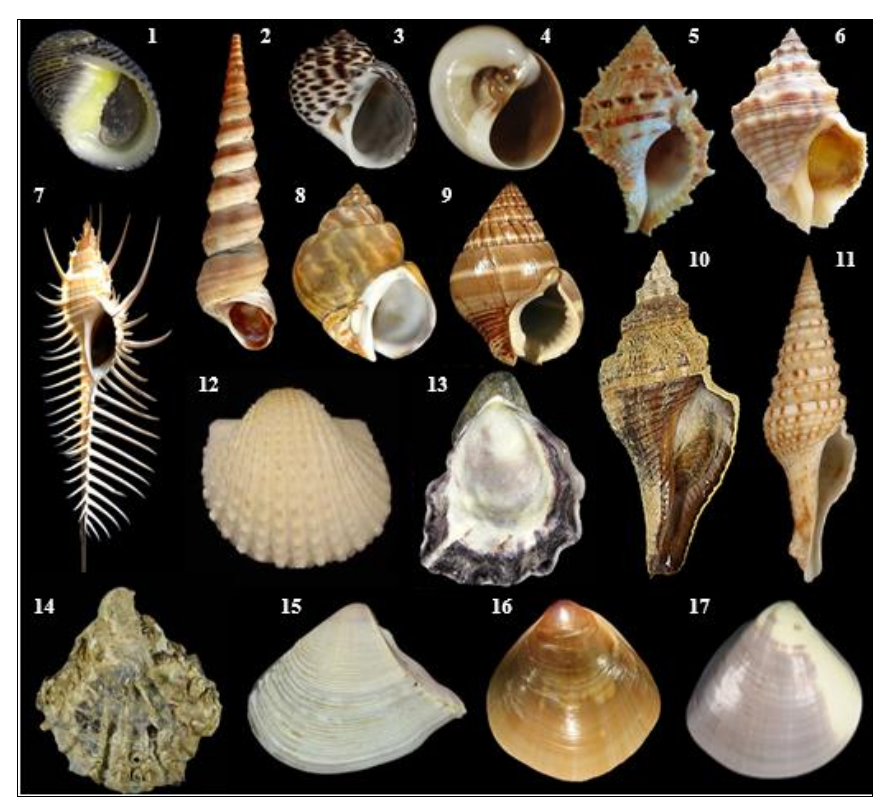

Fig 2(1-17): Intertidal gastropods and bivalves in study area. (1) Nerita lineata Gmelin, 1791, (2) Turritella duplicata (Linnaeus, 1758), (3) Natica tigrina (Röding, 1798), (4) Polinices didyma (Röding, 1798), (5) Bursa elegans (G. B. Sowerby I, 1835), (6) Thais mutabilis (Link, 1807), (7) Murex pecten Lightfoot, 1786, (8) Babylonia formosae (G. B. Sowerby II, 1866), (9) Nassarius olivaceus (Bruguière, 1789), (10) Pugilina ternatana (Gmelin, 1791), (11) Turris unedo Kiener, 1839, (12) Anadara granosa (Linnaeus, 1758), (13) Saccostrea cuccullata (Born, 1778), (14) Crassostrea gigas (Thünberg, 1793), (15) Donax scortum (Linnaeus, 1758), (16) Mactra mera Reeve, 1854, (17) M. violacea Gmelin, 1791.

\section{Description of shell characteristics in study area}

Nerita lineata Gmelin, 1791

\begin{tabular}{|c|c|c|}
\hline Shell shape & $:$ & Neritic form \\
\hline Spiral whorl & $:$ & Apex is blunt, low, many concentric lines \\
\hline Body whorl & $:$ & Large, swollen with both side \\
\hline Aperture type & $:$ & Wide, broad, slightly rounded \\
\hline Columella type & $:$ & Thick or thin present, sometime absent \\
\hline Operculum type & $:$ & Calcareous \\
\hline Umbilicus & $:$ & Absent \\
\hline Siphonal canal & $:$ & Absent \\
\hline Colouration & $:$ & Yellowish background, many black spiral lines \\
\hline Shell size & $:$ & 2.5 cm height, 3 cm width \\
\hline
\end{tabular}

\begin{tabular}{|c|c|c|}
\hline Shell shape & $:$ & Turriform \\
\hline Spiral whorl & $:$ & Long and narrow but slightly broad to body whorl \\
\hline Body whorl & $:$ & Globose, short \\
\hline Aperture type & $:$ & Oval to rounded \\
\hline Columella type & $:$ & Narrow, slightly curve, thick \\
\hline Operculum type & $:$ & Chitinous form \\
\hline Umbilicus & $:$ & Absent \\
\hline Siphonal canal & $:$ & Absent \\
\hline Colouration & $:$ & Yellowish to pale orange, brownish with strong keel \\
\hline Shell size & $:$ & $12 \mathrm{~cm}$ height, $2.5 \mathrm{~cm}$ width \\
\hline
\end{tabular}


Natica tigrina (Röding, 1798)

\begin{tabular}{|c|c|c|}
\hline Shell shape & $:$ & Naticoid form \\
\hline Spiral whorl & $:$ & Blunt, small \\
\hline Body whorl & $:$ & Globose, large, wide body whorl \\
\hline Aperture type & $:$ & Semi circular shape \\
\hline Columella type & $:$ & Thin and straight \\
\hline Operculum type & $:$ & Chitinous form \\
\hline Umbilicus & $:$ & Present, wide and deep \\
\hline Siphonal canal & $:$ & Absent \\
\hline Colouration & $:$ & Covered with many brown spots \\
\hline Shell size & $:$ & $3 \mathrm{~cm}$ height, $3.5 \mathrm{~cm}$ width \\
\hline
\end{tabular}

Polinices didyma (Röding, 1798)

\begin{tabular}{|c|c|c|}
\hline Shell shape & $:$ & Naticoid form \\
\hline Spiral whorl & $:$ & Very low spiral with blunted apex \\
\hline Body whorl & $:$ & Large, solid and massive with smooth outer shell surface \\
\hline Aperture type & $:$ & Slightly rounded, narrow \\
\hline Columella type & $:$ & Thick with strong callus \\
\hline Operculum type & $:$ & Chitinous form \\
\hline Umbilicus & $:$ & Deep and narrow \\
\hline Siphonal canal & $:$ & Absent \\
\hline Colouration & $:$ & Pale yellowish brown, grayish white \\
\hline Shell size & $:$ & 2 cm height, 2.5 cm width \\
\hline
\end{tabular}

Bursa elegans (G. B. Sowerby I, 1835)

\begin{tabular}{|c|c|}
\hline Shell shape & Turbiniform \\
\hline Spiral whorl & Low, sharp apex, narrow suture \\
\hline Body whorl & Large, covered spiral blunted spines, strong longitudinal spiral threads \\
\hline Aperture type & Oval or slightly long \\
\hline Columella type & Long and thin \\
\hline Operculum type & Chitinous form \\
\hline Umbilicus & Present and shallow \\
\hline Siphonal canal & Present, deep and narrow, curved backward \\
\hline Colouration & Creamy white, bright yellowish brown \\
\hline Shell size & $7 \mathrm{~cm}$ height, $4.5 \mathrm{~cm}$ width \\
\hline
\end{tabular}

Thais mutabilis (Link, 1807)

\begin{tabular}{|c|c|c|}
\hline Shell shape & $:$ & Turbiniform \\
\hline Spiral whorl & $:$ & Apex is blunt, shallow sutures, narrow shoulders \\
\hline Body whorl & $:$ & Solid, large, covered with spiral lines \\
\hline Aperture type & $:$ & Rounded, narrow \\
\hline Columella type & $:$ & Strong and thick \\
\hline Operculum type & $:$ & Chitinous form \\
\hline Umbilicus & $:$ & Present, deep and wide \\
\hline Siphonal canal & $:$ & Present, short \\
\hline Colouration & $:$ & Brownish white, covered with black bands \\
\hline Shell size & $:$ & $4 \mathrm{~cm}$ height, $2.5 \mathrm{~cm}$ width \\
\hline
\end{tabular}

Murex pecten Lightfoot, 1786

\begin{tabular}{|c|c|c|}
\hline Shell shape & $:$ & Fusiform \\
\hline Spiral whorl & $:$ & Low spiral with blunted apex \\
\hline Body whorl & $:$ & Large, wide, low spiral line present and distinct longitudinal spines \\
\hline Aperture type & $:$ & Rounded and narrow \\
\hline Columella type & $:$ & Strong and thick \\
\hline Operculum type & $:$ & Chitinous form \\
\hline Umbilicus & $:$ & Present and shallow \\
\hline Siphonal canal & $:$ & Present, long like groove \\
\hline Colouration & $:$ & Yellowish white \\
\hline Shell size & $:$ & $7.5 \mathrm{~cm}$ height, $4 \mathrm{~cm}$ width \\
\hline
\end{tabular}

Babylonia formosae (G. B. Sowerby II, 1866)

\begin{tabular}{|c|c|c|}
\hline Shell shape & $:$ & Naticoid form \\
\hline Spiral whorl & $:$ & Low, slightly deep and narrow shoulder \\
\hline Body whorl & $:$ & Solid, large and covered with white and brown path, suture is deep \\
\hline Aperture type & $:$ & Narrow and oval \\
\hline
\end{tabular}




\begin{tabular}{|c|c|c|}
\hline Columella type & $:$ & Strong and thick \\
\hline Operculum type & $:$ & Chitinous form \\
\hline Umbilicus & $:$ & Oval and narrow \\
\hline Siphonal canal & $:$ & Present \\
\hline Colouration & $:$ & Brownish white patch \\
\hline Shell size & $:$ & $4 \mathrm{~cm}$ height, $2.5 \mathrm{~cm}$ width \\
\hline
\end{tabular}

Nassarius olivaceus (Bruguière, 1789)

\begin{tabular}{|c|c|c|}
\hline Shell shape & $:$ & Naticoid form \\
\hline Spiral whorl & $:$ & Narrow apex, spiral with shallow groove \\
\hline Body whorl & $:$ & Thick and slightly swollen \\
\hline Aperture type & $:$ & Oval and narrow \\
\hline Columella type & $:$ & Thin, straight \\
\hline Operculum type & $:$ & Chitinous form \\
\hline Umbilicus & $:$ & Absent \\
\hline Siphonal canal & $:$ & Present and slightly short \\
\hline Colouration & $:$ & Brownish grey to yellowish \\
\hline Shell size & $:$ & $3.5 \mathrm{~cm}$ height, $1.7 \mathrm{~cm}$ width \\
\hline
\end{tabular}

Pugilina ternatana (Gmelin, 1791)

\begin{tabular}{|c|c|c|}
\hline Shell shape & $:$ & Fusiform \\
\hline Spiral whorl & $:$ & Short, apex is blunted, broad shoulder with short spin \\
\hline Body whorl & $:$ & Large, solitary, massive erect huge spine \\
\hline Aperture type & $:$ & Wide and thick \\
\hline Columella type & $:$ & Thin and curve \\
\hline Operculum type & $:$ & Chitinous form \\
\hline Umbilicus & $:$ & Present (distinct when mature) \\
\hline Siphonal canal & $:$ & Present, long and slightly straight \\
\hline Colouration & $:$ & Yellowish grey to dark grey \\
\hline Shell size & $:$ & $8 \mathrm{~cm}$ height, $4.5 \mathrm{~cm}$ width \\
\hline
\end{tabular}

Turris unedo Kiener, 1839

\begin{tabular}{|c|c|c|}
\hline Shell shape & $:$ & Turriform \\
\hline Spiral whorl & $:$ & Slightly long, narrow to apex, distinct longitudinal ribs \\
\hline Body whorl & $:$ & Narrow, short \\
\hline Aperture type & $:$ & Thin and straight \\
\hline Columella type & $:$ & Calcareous \\
\hline Operculum type & $:$ & Oval and thin, \\
\hline Umbilicus & $:$ & Absent \\
\hline Siphonal canal & $:$ & Present, curve to backward \\
\hline Colouration & $:$ & Grayish yellow to gray \\
\hline Shell size & $:$ & 6 cm height, $2.3 \mathrm{~cm}$ width \\
\hline
\end{tabular}

Anadara granosa (Linnaeus, 1758)

\begin{tabular}{|c|c|c|}
\hline Shell shape & $:$ & Solid, thick, equivalve, broadly oval shape \\
\hline Umbonal type & $:$ & Hook like \\
\hline Muscular scar & $:$ & Present \\
\hline Ligament & $:$ & Internal \\
\hline Outer layer & $:$ & White parallel ribs, 2 or more layer teeth \\
\hline Inner layer & $:$ & Smooth and white \\
\hline Teeth pattern & $:$ & Granulated, small similar teeth \\
\hline Pallial sinus & $:$ & Present \\
\hline Colouration & $:$ & White to yellow brown \\
\hline Shell size & $:$ & 12 cm height, 2.5 cm width \\
\hline
\end{tabular}

Saccostrea cuccullata (Born, 1778)

\begin{tabular}{|c|c|c|}
\hline Shell shape & $:$ & Oyster like, circular to oval \\
\hline Umbonal type & $:$ & Large, no sculpture \\
\hline Muscular scar & $:$ & Close to pallial line \\
\hline Ligament & $:$ & Internal \\
\hline Outer layer & $:$ & Rough with thick \\
\hline Inner layer & $:$ & Pearly white \\
\hline Teeth pattern & $:$ & Converging toward \\
\hline Pallial sinus & $:$ & Present \\
\hline Colouration & $:$ & Internally white, external purple, black, brown, \\
\hline Shell size & $:$ & 4 cm height, $2.5 \mathrm{~cm}$ width \\
\hline \multicolumn{2}{|c}{} \\
\end{tabular}


Crassostrea gigas (Thünberg, 1793)

\begin{tabular}{|c|c|c|}
\hline Shell shape & $:$ & Wide oval, thick and very rugose \\
\hline Umbonal type & $:$ & Prominent and enrolled \\
\hline Muscular scar & $:$ & Single, dark \\
\hline Ligament & $:$ & Internal \\
\hline Outer layer & $:$ & Hard and oval \\
\hline Inner layer & $:$ & Concave, quite deep and cup-shaped \\
\hline Teeth pattern & $:$ & Sharp erosive, asymmetric \\
\hline Pallial sinus & $:$ & Present \\
\hline Colouration & $:$ & Whitish, inner shell white, deep purple outermost shell \\
\hline Shell size & $:$ & 4 cm height, 3.5 cm width \\
\hline
\end{tabular}

Donax scortum (Linnaeus, 1758)

\begin{tabular}{|c|c|c|}
\hline Shell shape & $:$ & Trigonal \\
\hline Umbonal type & $:$ & Darker hues \\
\hline Muscular scar & $:$ & Present, both side posterior and interior \\
\hline Ligament & $:$ & Radiating line \\
\hline Outer layer & $:$ & White, purplish, polished \\
\hline Inner layer & $:$ & Two cardinal tooth \\
\hline Teeth pattern & $:$ & Present \\
\hline Pallial sinus & $:$ & Dark green, variation color \\
\hline Colouration & $:$ & $4 \mathrm{~cm}$ height, $6 \mathrm{~cm}$ width \\
\hline Shell size & $:$ & \\
\hline
\end{tabular}

Mactra mera Reeve, 1854

\begin{tabular}{|c|c|c|}
\hline Shell shape & $:$ & Oval, triangular shape \\
\hline Umbonal type & $:$ & Prominent and elevated \\
\hline Muscular scar & $:$ & Two subequal adductor \\
\hline Ligament & $:$ & Internal brown \\
\hline Outer layer & $:$ & Thick smooth \\
\hline Inner layer & $:$ & Whitish \\
\hline Teeth pattern & $:$ & Interior cardinal teeth, V- shaped \\
\hline Pallial sinus & $:$ & Short and oval \\
\hline Colouration & $:$ & White, brown \\
\hline Shell size & $:$ & $4 \mathrm{~cm}$ height, $5 \mathrm{~cm}$ width \\
\hline
\end{tabular}

Matra violacea Gmelin, 1791

\begin{tabular}{|c|c|c|}
\hline Shell shape & $:$ & Large, thin, absolutely radiate \\
\hline Umbonal type & $:$ & Prominent and elevated \\
\hline Muscular scar & $:$ & Present, same side anterior and posterior \\
\hline Ligament & $:$ & Internal, well develop \\
\hline Outer layer & $:$ & Smooth with spiral line \\
\hline Inner layer & $:$ & Smooth \\
\hline Teeth pattern & $:$ & Cardinal tooth present \\
\hline Pallial sinus & $:$ & Rounded, shallow and non-confluent \\
\hline Colouration & $:$ & Violet \\
\hline Shell size & $:$ & $2.5 \mathrm{~cm}$ height, $3.5 \mathrm{~cm}$ width \\
\hline
\end{tabular}

Table 2: Habitats of some intertidal gastropods and bivalves in study area

\begin{tabular}{|c|c|}
\hline Species & $\begin{array}{l}\text { Habitats characterization } \\
\end{array}$ \\
\hline Nerita lineata Gmelin, 1791 & $\begin{array}{c}\text { Very common in the upper part of shores, often in crevices and pits of rock benches, or on } \\
\text { branches of littoral trees overhanging the water. }\end{array}$ \\
\hline Turritella duplicata (Linnaeus, 1758) & On sub-tidal sand and mud bottoms. \\
\hline Natica tigrina (Röding, 1798) & On sandy bottoms. Mainly sub-littoral, from shallow sub-tidal waters to a depth of about $30 \mathrm{~m}$. \\
\hline Polinices didyma (Röding, 1798) & On sandy to muddy bottoms. Intertidal to shelf zones. \\
\hline Bursa elegans (G. B. Sowerby I, 1835) & Mud and muddy-sand bottoms. \\
\hline Thais mutabilis (Link, 1807) & Common in various shallow water habitats, rocks, coral reefs, or clean to muddy sand bottoms. \\
\hline Murex pecten Lightfoot, 1786 & On sandy to muddy bottoms of coral reef areas and on the continental shelf. \\
\hline $\begin{array}{l}\text { Babylonia formosae (G. B. Sowerby II, } \\
1866)\end{array}$ & On sand and mud bottoms. \\
\hline Nassarius olivaceus (Bruguière, 1789) & Very common on muddy sand flats. \\
\hline Pugilina ternatana (Gmelin, 1791) & Common on soft bottoms. Sub-littoral and offshore, mainly at depths between 10 to $50 \mathrm{~m}$. \\
\hline Turris unedo Kiener, 1839 & $\begin{array}{l}\text { Common on sub-littoral muddy bottoms, to a depth } \\
\text { of about } 30 \mathrm{~m} .\end{array}$ \\
\hline
\end{tabular}




\begin{tabular}{|c|c|}
\hline Anadara granosa (Linnaeus, 1758) & On muddy bottoms, mainly in protected bays and estuaries, or in mangroves. \\
\hline Saccostrea cuccullata (Born, 1778) & $\begin{array}{c}\text { Attached to various hard substrates, in marine, estuarine and mangrove areas, often in dense } \\
\text { colonies. }\end{array}$ \\
\hline Crassostrea gigas (Thünberg, 1793) & $\begin{array}{c}\text { Attached to hard objects or growing in bunches, on various soft bottoms, especially in bays and } \\
\text { estuaries with somewhat reduced salinity. Intertidal and shallow sub-tidal water. }\end{array}$ \\
\hline Donax scortum (Linnaeus, 1758) & In muddy bottoms. Intertidal and shallow sub-tidal waters. \\
\hline Mactra mera Reeve, 1854 & In sandy bottoms. \\
\hline M. violacea Gmelin, 1791 & In sandy bottoms, at shallow sub-tidal levels. \\
\hline
\end{tabular}

Molluscs are for the most part of benthonic but gastropods have developed those pelagic groups: janthinids, heteropods and pteropods, all of which have been represented in Myanmar waters [7]. Bivalves are soft-bodied mollusks enclosed by two valves joined by an elastic ligament. The mollusks are very common in aquatic environments, including freshwater, brackish water, and saltwater ${ }^{[21]}$.

In Myanmar, the earliest reports on marine shell fish had been

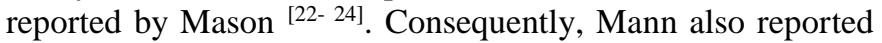
on Burmese molluscs along three coastal waters of Myanmar [25]. In the 1980s, Mar Lar Myo Sein, Soe Thu and Aye Thida Thein reported a common species of brackish-water molluscs inhabit in Rakhine coastal region ${ }^{[8,26-27]}$. Soe Thu had also recorded the diversity of seashells from Ngapali, Maungmagan and various localities of Myanmar coastal waters ${ }^{[28-30]}$. In the recent year 2019, Naung Naun Oo had studied Turban shells of Andrew Bay, southern Rakhine costal region ${ }^{[31]}$.

In the Ayeyarwady Coastal Region, Aye Thant Zin et.al had been reported preliminary survey of gastropods and Pelecypods around the Sin-Ma village, Pathein Township ${ }^{[17]}$. In the year 2011, the spat collection grown out culture of oyster in Shwe Thaung Yan coastal area had been carried out by Htay Aung ${ }^{[32]}$.

In Taninthayi Coastal Region, Kyaw Myint had published a checklist comprising 248 species of marine gastropods, bivalves and cephalopods in Moscos Islands. His reported list included 72 families but was not yet perfect checklist in Myanmar [33]. A systematic account on some marine gastropods, pelecypods (= Bivalves) and cephalopods in various localities of Myanmar had been carried out by Jar San reported morphology and distribution cephalopods in Mon coastal areas ${ }^{[34]}$, Naung Naung Oo had conducted the study of the marine gastropods from the Mon Coastal area [35]. Moreover, Thaw Zin Naing Tun et.al, Phoo Thet Su Win, Sint Sint Hlaing, Khin Myo Thin, Su Pyae Tun, Aung Ko Latt, Aung Pyae Phyo and Win Win Nwe had studied about the estuarine and marine mollusks in their respectively along Myanmar coastal water [17, 36-43]. However, distribution pattern, habitat preferences and seasonal variation remained unknown to give much more information.

Currently reported all bivalves' species are providing not only harmony for intertidal habitats but also utilized food for local consumption. Bivalves are mostly found in mudflat while gastropods inhabit all types of habitats. In the sand beach, 2 species of bivalves; Mactra mera (Reeve, 1854), M. violacea (Gmelin, 1791) and 3 species of gastropods; Turritella duplicata (Linnaeus, 1758), Natica tigrina (Röding, 1798) and Murex pecten (Lightfoot, 1786) were collected, in which the highest number of T. duplicata (Linnaeus, 1758) are found in sandy beach. These species have been used to create ornamentation found in souvenir shop for selling local markets. The muddy sand habitat of Thae Chaung intertidal water, 6 species of gastropods and 4 species of bivalves were found. Maximum number of molluscs was recorded in this habitat. Local people have used Pugilina ternatana (Gmelin,
1791) as food for fishery purposes. Approach to the rocky fringe, Nerita lineata Gmelin, 1791 and Thais mutabilis Link, 1807 was recorded from different habitats at intertidal zone such as mudflat, sandy beach and tide pool, the lowest number of species occurred in this area.

\section{Conclusion}

A total of 17 species of molluscs were found in the present study area. The result might not represent the actual diversity because there was a preliminary checklist survey which represented a small scale area of northern Rakhine coast. However, this paper will help everybody who need fundamental checklist of molluscs species data. Extended study should be conducting seasonally collecting mollusks data in intertidal to deep water. Using advanced methods will evaluate specific value. Long term data collections supported to determine seasonal abundance and distribution to study the adaptation between mollusks diversity and environmental condition in study areas.

\section{Acknowledgements}

The authors are grateful to Dr. Win Naing, who is responsible for Rector and Dr. Khin Maung Zaw, Pro-rector of Sittway University, for supporting this work. And we would like to thank Dr. Mra Kyawt Wai, Professor and head of Department of Marine Science, Sittway University, for the encouragement and great idea in this paper. Thanks so much to colleague, Htoo Lwin Aung who assisted on making the research station map.

\section{References}

1. Holmes KE, Tun T, Latt KT et al. Marine Conservation in Myanmar: The current knowledge of marine system and recommendations for research and conservation. Yangon, WCS and MSAM, 2014, 204.

2. Myanmar Aquaculture and Inland Fisheries. FAO 2003. http;//www.fao.org/decrep/004 /ad497e/ad497e00.htm.

3. Brusca RC, Brusca. Invertebrates, Sinauer Associates, Sunderland, Mass, USA 1990.

4. Hendrickx ME, Brusca RC, Cordero M, Ram'irez G. "Marine and brackish-water molluscan biodiversity in the Gulf of California, Mexico 2007;71(4):637-647

5. Benkendorff K. Molluscan biological and chemical diversity: Secondary metabolites and medicinal resources produced by marine molluscs. Biological Reviews 2010:85(4):757-775.

6. Bouchet P, Duarte CM. The exploration of marine biodiversity: Scientific and technological challenges. Fundaci'on BBVA 2006;33:1-34.

7. Thu S. Taxonomy and distribution of Burmese marine gastropods. Unpublished M.Sc. Thesis. Department of Zoology, Arts and Science University, Rangoon 1980.

8. Sein MLM. The taxonomy and distribution of Burmese marine bivalves. Unpublished MSc Thesis, Department of Zoology, Art and Science University, Rangoon. Burma 1982. 
9. Ponder W, Lindberg DR. Phylogeny and evolution of the mollusca. Oakland, CA: University of California Press 2008.

10. http;//www.mesa.edu.au.com. 25 Jan, 2021.

11. Chakraborty C, Hsu CH, Wen ZH, Lin CS. Anticancer drugs discovery and development from marine organisms. Current Topics in Medicinal Chemistry 2009;9(16):1536-45.

12. Harris $M$, Weisler $M$. Prehistoric Human Impacts to Marine Mollusks and Intertidal Ecosystems in the Pacific Islands, The journal of Island and Coastal Archeology 2017;13(2):235-255

13. Dance SP. Smithsonian Handbooks Shells. A Dorling Kindersley Book 2002, 256.

14. Feinberg HS. Simon \& Schuster Guide To Shells. Simon \& Schuster New York 2003, 511.

15. Win M et al. Morphology and taxonomy of some marine molluscs in coastal waters of Burma 1975.

16. Thu TT. Taxonomic on some marine bivalves of Dawei, Myeik and Kawthaung along Taninthayi coast, Unpublished MSc Thesis, Department of Zoology, Art and Science University, Rangoon 1998.

17. Zin AT, Khaing LL, Lwin CC. Perliminary survey of gastropods and Pelecypods around the Sin-Ma village, Pathein Township. Unpublished Term paper, Department of Zoology, Pathein University, Pathein, Myanmar 2007.

18. Tun TZN, Kyaw AM, Aung PW. Preliminary Survey of Gastropods and Pelecypods around Kanpani Village, Longlone Township, Taninthayi Region. Unpublished BSc. Term Paper, Department of Marine Science, Mawlamyine University, Mawlamyine, Myanmar 2012.

19. Oo NN. Study on the marine gastropods from Mon coastal areas. Unpublished MRes Thesis, Department of Marine Science, Mawlamyine University, Myanmar 2012.

20. Hossain MS et al, Sea Shells of Bangladesh: Marine Gastropod and Bivalve Molluscs Biodiversity 2014

21. Poutiers JM. Bivalves. In: Carpenter KE, Niem VH, editor. FAO Species Identification Guide for Fishery Purposes. The Living Marine Resources of the Western Central Pacific. Volume 1. Seaweeds, Corals, Bivalves and Gastropods. Food and Agriculture Organization, Rome 1998, 123-362.

22. Mason RF. The natural productions of Burma or "Notes on the fauna, flora and minerals of the Tenasserim provinces and the Burma Empire". American Mission Press, Moulmein 1850, 211.

23. Mason RF. Tenasserim or Notes on the fauna, flora, minerals and nations of British Burma and Pegu: with systematic catalogues of the known minerals, plants, mammals, fishes, molluscs, sea-nettles, corals, sea urchins, worms, insects, crabs, reptiles and birds: with vernacular names. American Mission Press: Moulmein 1852, 550.

24. Mason RF. Burma, its people and production. Notes on the fauna, flora and minerals of Tenasserim, Pegu and Burma. Volume 1: Geology, Mineralogy and Zoology. Stephen Austin and Sons Company Ltd, Hertford 1882, 220.

25. Mann JGD. Fauna of Mergui Archipelago. Marine Zoology, Taylor and Francis, London 1888;1(1):56-80.

26. Thu S. Taxonomy and distribution of Burmese marine gastropods. Unpublished MSc Thesis, Department of Zoology, Art and Science University, Rangoon. Burma
1980.

27. Thein AT. The taxonomic studies on the Burmese marine nerites (Gastropoda: Neritidae). Unpublished MSc Thesis, Department of Zoology, Art and Science University, Rangoon. Burma 1982.

28. Thu S. Sea shells of Ngapali. University Education Journal 1970;5(1):317-368.

29. Thu S. Sea shells of Maungmagan. University Education Journal 1971;6(2):397-432.

30. Thu S. The Sea Shells. Ministry of Information. Yangon 1972, 63.

31. OO NN, Ko KZ, Tint MMK. Turban shells of Andrew Bay in Rakhine coastal region of Myanmar, Journal of Aquaculture \& Marine Biology 2019;8(2):63-67.

32. Aung H. Study on the spat collection and grows out culture of oyster in Shwe Thaung Yan coastal area. Unpublished PhD. Dissertation, Department of Marine Science, Mawlamyine University. Myanmar 2011.

33. Myint K. Check list of Molluscs of the Mergui Archipelago and theMoscos Islands. University Education Journal 1971;6(2):37-48.

34. San J. Studies on the morphology and distribution cephalopods in Mon coastal areas. Unpublished MSc. Thesis, Department of Marine Science, Mawlamyine University. Myanmar 2011.

35. OO NN. Study on the marine gastropods from Mon coastal areas. Unpublished MRes Thesis. Department of Marine Science, Mawlamyine University. Myanmar 2012.

36. Win PTS. Study on the marine gastropods and pelecypods from Setse and Kyaikkhami coastal areas. Unpublished MSc Thesis. Department of Marine Science, Mawlamyine University. Myanmar 2012.

37. Win PTS. A study on the marine pelecypods from Mon coastal areas. Unpublished Mres Thesis. Department of Marine Science, Mawlamyine University. Myanmar 2013.

38. Hlaing SS. Study on the bivalve near the shell dunes near Pyin Bu Gyi Village, Palaw Township, Taninthayi Region. Unpublished MSc. Thesis, Department of Marine Science, Myeik University, Myeik. Myanmar 2012.

39. Thin KM. A study on the occurrence and distribution of Polymesoda expansa Mousson, 1758 (Corbiculidae, Mollusca) from Zee-Phyu-Thaung coastal areas, Ye Township, Mon State. Unpublished MSc. Thesis, Department of Marine Science, Mawlamyine University. Myanmar 2015.

40. Tun SP. The composition and distribution of benthic mollusks along southern Taninthayi Coastal Region. Unpublished MSc Thesis, Department of Marine Science, Mawlamyine University. Myanmar 2016.

41. Latt AK. Study on the gastropods and pelecypods of Kawdut coastal area, Ye Township in Mon State. Unpublished MRes Thesis, Department of Marine Science, Mawlamyine University. Myanmar 2017.

42. Phyo AP. Bivalve molluscs of Mon coastal area with special reference for habitat, local distribution and utilization. Unpublished MSc. Thesis, Department of Marine Science, Mawlamyine University. Myanmar 2019.

43. Nwe WW. Biology and culture of green mussel Perna viridis (Linnaeus, 1758) from Ye estuary in Mon State. Unpublished PhD. Dissertation, Department of Marine Science, Mawlamyine University. Myanmar 2019. 